\title{
Barriers to sustaining customer participation in hospital-based farmers' markets: insights from employees
}

\author{
Daniel R. George ${ }^{* 1}$, Jennifer L. Kraschnewski ${ }^{2}$, Liza S. Rovniak ${ }^{2}$, Lindsay Vaughn ${ }^{3}$, Judy Dillon ${ }^{4}$ \\ ${ }^{1}$ Department of Humanities, Penn State College of Medicine, Hershey, Pennsylvania, USA \\ ${ }^{2}$ Departments of Medicine and Public Health Sciences, Penn State Hershey Medical Center, Hershey, PA, USA \\ ${ }^{3}$ Penn State School of Nutrition, Hershey, Pennsylvania, USA \\ ${ }^{4}$ Penn State School of Nursing, Hershey, Pennsylvania, USA
}

Received: January 18, 2015

DOI: $10.5430 /$ jha.v4n3p20
Accepted: March 19, 2015

Online Published: March 31, 2015

\begin{abstract}
92 farmers' markets are located on hospital campuses in the United States but no known studies have evaluated factors influencing employee use of on-site markets. We examine modifiable barriers that reduced employee participation in a hospital-based market at Pennsylvania State Hershey Medical Center. 360 employees of Pennsylvania State Hershey Medical Center who used a weekly on-site seasonal market less than twice annually were sent an online survey, and frequency of response data were analyzed. Most frequently referenced barriers to participation were: location/access to the market, personal work schedules, cost of market products, and hours of operation, while top perceived benefits were support of local agriculture, health benefits, atmosphere/environment, and affordability. Hospital markets using value-based marketing campaigns to promote local economic and individual health benefits of participation, maximize convenience and access, and incentivize attendance are likely to sustain employee participation. These modifiable features may be relevant to worksite markets in diverse regions.
\end{abstract}

Key Words: Nutrition, Worksite health, Health protective behavior, Worksite health promotion, Farmers market

\section{INTRODUCTION}

Farmers markets, defined as recurrent organizations at fixed locations where vendors sell farm products and other goods ${ }^{[1]}$ may serve public health in multi-faceted ways: increasing fruit and vegetable consumption, promoting sustainable environments through the consumption of local foods, and encouraging social interaction and physical activity. ${ }^{[2,3]}$

There has been a recent trend towards the establishment of markets on healthcare campuses, as such partnerships may augment the provision of comprehensive, patient-centered care, ${ }^{[4]}$ and serve community health. ${ }^{[5]}$ Nearly 100 markets currently exist on hospital campuses. ${ }^{[2]}$ New legislation in the US - including the Affordable Care Act and related Internal Revenue Service requirements for nonprofit hospitals to complete regular community needs assessments and locallytailored action plans to maintain tax-exempt status and avoid a $\$ 50,000$ excise tax ${ }^{[6]}$ - could further accelerate the growth of markets based at healthcare institutions. However, ensuring that markets can serve as a sustainable partner within healthcare institutions requires ongoing customer patronage from hospital employees, patients, and community members.

*Correspondence: Daniel R. George; Email: dgeorge1@ @hmc.psu.edu; Address: Department of Humanities, Penn State College of Medicine, 500 University Dr., Hershey, PA, USA. 
As hospital employees represent the majority of customers at existing hospital-based markets, ${ }^{[7,8]}$ their regular patronage may be especially significant to the success of worksite markets. While existing studies have examined perceived benefits and barriers to markets amongst community-based shoppers, ${ }^{[9-11]}$ no known studies have evaluated factors that influence hospital employee use of an on-site market. The purpose of this study was to explore the barriers to utilization of a market at Pennsylvania State Milton S. Hershey Medical Center (PSMHC) from the perspective of employees, focusing particularly on persons who have underutilized the market. Since this population works in healthcare but generally declines to attend market, it was believed that their views could provide insights on how administrators of future market initiatives could enhance participation.

\section{METHOD}

This study took place at PSMHC in Hershey, Pennsylvania (USA). The medical center has approximately 10,000 employees and supports a seasonal market that opened in 2010. Each Thursday, 2:30 - 6:30 pm from May through October, the market offers produce and other specialty items from local vendors as well as free children's programming, musical acts, wellness information, and health screenings (i.e. blood pressure, body mass index [BMI], dietary coaching, etc.). Market offerings are promoted via internal listservs and digital bulletin boards within PSHMC.

The Institutional Review Board at PSHMC approved this study prior to data collection. Online surveys were created using Survey Monkey and emailed via internal listservs to a random sample of 700 employees that was generated by Human Resources. Recipients were provided a secure link to an introductory page that explained the nature and pur- pose of the study, and that completion of the survey implied informed consent. Because the study sought to examine perceptions of employees who did not regularly attend the market, participants were screened for frequency of market attendance, with those who visited the market less than twice during the prior 25-week market season being invited to take the survey. The survey included three multiple-choice questions that asked participants to identify what they perceived as major barriers to and benefits of participation, as well as services they most desired. Participants were also provided qualitative fields to contribute open-ended perceptions of the market and suggest improvements. The survey was open for two weeks in August 2012 and took participants an average of four minutes to complete. Frequency of response data were analyzed using SPSS, version 21.

\section{ReSUlts}

The population surveyed had a mean age of 42 , was $74 \%$ female, and $87 \%$ white. Of the 700 employees who received the link, 340 (49\%) were ineligible due to frequent market attendance. Of the remaining 360 eligible employees (51\%), 81 employees completed the survey, representing a $23 \%$ response rate (81/360). The most frequently referenced barrier to participation was the location/access to the market (37\%). Personal work schedules $(22 \%)$, cost of market products (17\%) and the market's hours of operation (14\%) were also identified as significant barriers. Other reasons for not attending included: forgetting about the market (12\%), and not being aware of the market or sure of its exact location (10\%). The perception of greater relative expense of products sold at the market, lack of food variety, and a preference for "onestop shopping" at a supermarket were identified as "other" barriers (see Table 1).

Table 1. Survey results

\begin{tabular}{|c|c|c|}
\hline & Survey questions & Frequency of participant \\
\hline \multirow[t]{9}{*}{ Perceived barriers to participation in market } & Location or access to the market & $37 \%(30)$ \\
\hline & Personal or work schedule & $22 \%(18)$ \\
\hline & Cost of farmers' market products & $17 \%(14)$ \\
\hline & Market hours of operation & $14 \%(11)$ \\
\hline & Forget about the market & $12 \%(10)$ \\
\hline & Lack of food variety & $12 \%(10)$ \\
\hline & I do not know where the market is located & $10 \%(8)$ \\
\hline & Food safety concerns & $2 \%(2)$ \\
\hline & Other & $9 \%(7)$ \\
\hline \multirow[t]{5}{*}{ Perceived benefits of participation in market } & Support of local agriculture & $85 \%(69)$ \\
\hline & Health benefits & $64 \%(52)$ \\
\hline & Atmosphere/Environment & $42 \%(34)$ \\
\hline & Affordability & $20 \%(16)$ \\
\hline & Other & $7 \%(6)$ \\
\hline \multirow[t]{4}{*}{ Desired services at market } & No response & $47 \%(38)$ \\
\hline & Health screenings and outreach services & $19 \%(15)$ \\
\hline & Nutrition and agricultural information & $15 \%(12)$ \\
\hline & Cooking demonstrations and recipes & $7 \%(6)$ \\
\hline
\end{tabular}


Respondents indicated that the primary perceived benefit to market participation was support of local agriculture (85\%), although health benefits (64\%), atmosphere/environment $(42 \%)$, and affordability (20\%) were also commonly mentioned as positive attributes.

Twenty participants provided open-ended feedback about the market. Commonly suggested improvements included: extending hours, providing price comparisons between market and grocery store products, offering free recipes and cooking demonstrations, advertising weekly sale items on the hospital website, and using internal listservs to address the perception of the market being expensive. Participants commented that the market, because of its inconvenient location and hours, represented an additional trip for them, and that most shopping was done once per week at the grocery. They also expressed concern about wasting food purchased mid-week (i.e. Thursday). Additionally, participants indicated that the market was more expensive and chose to reserve their visits for special occasions. The main benefits to utilization were perceived as supporting local small businesses and having access to fresh, unique produce.

\section{Discussion}

Our finding that 49\% (340/700) of PSHMC employees reported as frequent market attendants is comparable to percentages previously reported at Duke Hospital (40\%) and The Cleveland Clinic (55\%). ${ }^{[8]}$ With regard to barriers, results from this survey of hospital employees were consistent with previous surveys conducted on barriers to market participation among community-dwelling subjects. ${ }^{[9-11]}$ Location and access to the market, and perceived expense of produce were considered major barriers to participation, while support of local agriculture, perceived health benefits, community atmosphere and affordability were perceived as primary benefits. Time constraints and hours of operation were not cited as barriers in the aforementioned studies on communitydwelling participants, but were identified as major barriers for hospital employees, which is perhaps unsurprising due to the demanding nature and regimented scheduling of work in the healthcare field. Participants in the study frequently requested services already offered at the market such as information on a healthy diet, free health screenings, and health information, indicating a lack of awareness within the hospital employee base about such services.

These results have direct relevance for current and future efforts to develop sustainable markets on other hospital campuses and in other workplace/community settings. To increase utilization among employees and community members, it may be critical to situate markets at hospitals/workplaces in central locations that maximize convenience and that are well integrated into existing walking or driving routes of employees rather than being freestanding units requiring an intentional trip. Markets designed to provide immediate access on frequently travelled pedestrian and automobile routes may have the greatest chance of long-term success, consistent with research supporting the importance of proximal environmental influences on health behavior. ${ }^{[12]}$ If central space for a market is not possible on hospital or other work campuses, it may be worthwhile to consider smaller on-site "satellite" market stands or Community Shared Agriculture (CSA) pickup locations that could occupy less space and be set up centrally within a healthcare facility.

Further, we noted contradictory views in that respondents rated cost of farmers' market products (or affordability) as a major perceived barrier, but also identified affordability as a major perceived benefit. It is likely that different types of products are perceived as more affordable than others $(e . g$. fruits and vegetables sold at market generally compare favorably to supermarket and grocery store prices versus meats which tend to be more expensive at markets compared to supermarkets and grocery stores). ${ }^{[13-15]}$ It may therefore be helpful for markets to promote price comparisons between specific products at markets versus non-markets so that attendance is not deterred by perceptions related to higher cost products. It would also seem valuable to educate employees as to the reasons for the higher costs associated with certain locally produced products such as meats (e.g. humane care of animals, better nutritional profile of meat, etc.). Moreover, offering discounts for employees who visit markets and purchase healthy products - perhaps subsidized by employee wellness programs - may provide an incentive for persons who feel price differential to be a major barrier for participation. Our results substantiate existing arguments to use value-based marketing campaigns to overcome barriers to participation. ${ }^{[16]}$ Specifically, it would seem that appealing to the notion of employee participation at markets ultimately supporting the wellbeing of local farmers and small businesses and therefore stimulating the local economy would be a strategy capable of enhancing market patronage. Moreover, it may be advisable for current and future hospital-based markets to diversify services offered - such as free health screenings and nutrition education, etc. - and leverage institutional communications to more effectively promote desired services.

There are several limitations to this study. The $23 \%$ response rate was low, but not unexpected since participants were asked to take time to comment on a service they generally did not use, and was consistent with the response rate 
$(<25 \%)$ typically seen for surveys of health practitioners. ${ }^{[17]}$ The survey and focus groups were conducted on a random sample of hospital employees at only one site in a rural area, which limits generalizability to other hospital-based markets, particularly those in urban settings. The absence of more specific demographic information - particularly with regard to professional background and income - is an additional limitation. Results may also be biased due to the nonprobability sampling strategy and the possibility that employees who had greater relative interest in potentially utilizing markets would be more likely to participate in the survey. Furthermore, this study looks only at hospital workers, who may differ from employees in other workplaces, especially with regard to barriers to participating in workplace-based markets. Hospital workers generally have highly regimented schedules that may offer relatively little flexibility and time for workday activities such as shopping. Moreover, the market at PSHMC is somewhat unique in that it is an academic health center located in a rural/residential area. Markets at hospitals/workplaces in more urban areas may have variable environmental aspects that encourage or discourage attendance, for instance: residential population density near the market, space to park near the market, the number of grocery stores existing in close proximity to the market, percentages of persons enrolled in federal supplemental nutrition assistance programs, etc. Administrators must consider these contextual elements in the planning and assessment of future markets.

Ultimately, based on the barriers to market utilization identified in this study and in similar studies, ${ }^{[9-11]}$ future research should test the effects of altering variables such as market locations, or broadening the range of products and services offered, to enhance market attendance. These barriers are likely relevant not only to hospital or other employees, but also to diverse community members in rural and urban areas. Using value-based approaches to address these modifiable influences on attendance will be critical to establishing markets as sustainable healthcare partners that can contribute to meeting the preventive health requirements of the Affordable Care Act.

\section{ACKNOWLEDGEMENTS}

The researchers report no funding for this study. Dr. Kraschnewski is supported by the National Center for Advancing Translational Sciences, NIH, Grants UL1TR000127 (Sinoway) and KL2TR000126. Procedures followed were in accordance with the ethical standards of the responsible committee on human experimentation (institutional and national) and with the Helsinki Declaration of 1975, as revised in 2000 .

\section{CONFLICTS OF INTEREST Disclosure}

We declare no potential conflicts of interest with respect to the research, authorship, and/or publication of this article.

\section{REFERENCES}

[1] Brown A. Counting farmers markets. Geographical Review. 2001; 91: 655-675. http://dx.doi.org/10.2307/3594724

[2] George DR, Kraschnewski JL, Rovniak LS. Public Health Potential of Farmers' Markets on Medical Center Campuses: A Case Study from Penn State Milton S. Hershey Medical Center. American Journal of Public Health. 2011; 10(1): 2226-2232. PMid: 22021298. http://dx.doi.org/10.2105/AJPH.2011.300197

[3] Kamphuis CB, Gisks K, de Bruijin GJ, et al. Environmental determinants of fruit and vegetable consumption among adults: A systematic review. British Journal of Nutrition. 2006; 96: 620-635. PMid: 17010219

[4] American Academy of Family Physicians, American Academy of Pediatrics, American College of Physicians, and American Osteopathic Association. Joint principles of the patient-centered medical home. 2009. Available from: http://www.acponline.org/advocacy /where_we_stand/medical_home/approve_jp.pdf. Updated March 1, 2007. Accessed June 30, 2009.

[5] Kaiser Permanente. A comprehensive list of farmers' markets. Available from: https://members.kaiserpermanente.org/redir ects/farmersmarkets. Accessed February 2, 2013.

[6] Patient Protection and Affordable Care Act, Section 9007. Available from: http://www.gpo.gov/fdsys/pkg/BILLS-111hr3590en

Published by Sciedu Press
r/pdf/BILLS-111hr3590enr .pdf. Accessed March 17, 2014.

[7] George DR, Rovniak L, Kraschniewski J, et al. Medical center farmers' markets: A strategic partner in the Patient-Centered Medical Home. Preventing Chronic Disease. 2013; 10: E127. http: $/ /$ dx.doi.org/10.5888/pcd10.130105

[8] Kraschnewski J, George DR, Rovniak L, et al. Characterizing customers at medical center farmers' markets. Journal of Community Health. 2014; 39: 727-731. PMid: 24421001. http://dx.doi.org /10.1007/s10900-014-9818-x

[9] McCormack LA, Melissa LN, Larson NI, et al. Review of the Nutritional Implications of Farmers' Markets and Community Gardens: A Call for Evaluation and Research Efforts. Journal of the American Dietetic Association. 2010; 110: 399-408. PMid: 20184990 http://dx.doi.org/10.1016/j.jada.2009.11.023

[10] Herman DR, Harrison GC, Afifi AA, et al. Effect of a Targeted Subsidy on Intake of Fruits and Vegetables Among Low-Income Women in the Special Supplemental Nutrition Program for Women, Infants, and Children. American Journal of Public Health. 2008; 98: 98-105. PMid: 18048803. http://dx.doi.org/10.2105/AJPH. 2005.0 79418

[11] Racine EF, Vaughn AS, Laditka SB. Farmers' Market Use Among African-American Women Participating in the Special Supplemental Nutrition Program for Women, Infants, and Children. Jour- 
nal of the American Dietetic Association. 2010; 110: 441-446.

PMid: 20184995. http://dx.doi.org/10.1016/j.jada. 2009

.11 .019

[12] Sallis JF, Floyd MF, Rodriguez DA, et al. Role of built environments in physical activity, obesity, and cardiovascular disease. Circulation. 2012; 125(5): 729-737. PMid: 22311885. http://dx.doi.org/1 0.1161 /CIRCULATIONAHA. 110.969022

[13] Larsen K, Gilliland J. A farmers' market in a food desert. Evaluating impacts on the price and availability of healthy food. Health and Place. 2009; 15: 1158-1162. PMid: 19631571. http://dx.doi.o $\mathrm{rg} / 10.1016 / \mathrm{j}$.healthplace. 2009.06.007

[14] Lee RE, Heinrich KM, Medina AV, et al. A picture of the healthful food environment in two diverse urban cities. Environmental Health
Insights. 2010; 4: 49-60. PMid: 20706621. http://dx.doi.org /10.4137/EHI.S3594

[15] McGuirt JT, Jilcott Pitts SB, Ammerman AS. Produce price savings for consumers at farmers' markets compared to supermarkets in North Carolina. Journal of Hunger \& Environmental Nutrition. 2011; 6: 8698. http://dx.doi.org/10.1080/19320248.2010.551031

[16] Cantor A, Strochlic R. Breaking Down Market Barriers for Small and Mid-Sized Organic Growers. California Institute for Rural Studies. 2009. Available from: http: //www . ams .usda.gov. Accessed 14 June, 2012.

[17] Wiebe ER. Why are response rates in clinician surveys declining? Canadian Family Physician. 2012; 58(4): e225-e228. PMid: 22611609. 